\title{
MOLECULAR INTERACTION OF THE DOWNSTREAM EXECUTIONER CYSTEINE ASPARTYL PROTEASES (CASPASE-3 AND CASPASE-7) WITH CORILAGIN, QUERCETIN, RUTIN, KAEMPFEROL, GALLIC ACID, AND GERANIIN OF Acalypha wilkesiana Müll.Arg.
}

\author{
S. Megantara ${ }^{1}$, M. Mutakin ${ }^{1}$, E. Halimah ${ }^{2}$, E. Febrina ${ }^{2}$ and J. Levita, \\ ${ }^{1}$ Department of Pharmaceutical Analysis and Medicinal Chemistry, Universitas Padjadjaran, \\ Sumedang-45363, (West Java) Indonesia \\ ${ }^{2}$ Department of Pharmacology and Clinical Pharmacy, Universitas Padjadjaran, Sumedang- \\ 45363, (West Java) Indonesia \\ *E-mail: jutti.levita@unpad.ac.id
}

\begin{abstract}
Apoptosis is caused by activation of caspases, i.e. intracellular cysteine proteases which cleave their substrates at aspartic acid residues. Caspases are categorized into (1) the initiator caspases (caspase-9) and (2) the executioner caspases (caspases-3 and -7). The ethanolic extract of Acalypha wilkesiana Müll.Arg suppressed the growth of human breast cancer cell lines and showed cytotoxicity against cervical cancer cell lines and human skin keratinocyte cell lines. Our work studied the structure-based molecular interaction of the caspases and this plant. The X-ray crystal structure of human caspase-3 and -7 were downloaded from https://www. rcsb.org/structure/. The ligands were built using LigandScout software and were subjected to energy minimization using the molecular mechanic forcefield partial charges in LigandScout. The energy-minimized ligands were docked to caspase-3 and caspase-7. The results indicated that kaempferol possesses a similar binding mode in terms of hydrogen bond (Arg64, Gln161, His121, Tyr204 in caspase-3; Cys290 in caspase-7) and hydrophobic interaction (Trp206 in caspase-3; Tyr223, Phe221, Ile183, Val292 in caspase-7), with that of the caspase substrate with better affinity. The binding mode of rutin resembles that of 2-(2,4 dichloro phenoxy)-N-(2-mercapto-ethyl)-acetamide in caspase-7 with better affinity. In conclusion, kaempferol, and rutin, two flavonoids in Acalypha wilkesiana Müll. Arg might be able to inhibit the downstream executioner caspases, particularly caspase- 3 and caspase-7. The binding affinity of these compounds against caspases is better than the standards.

Keywords: Apoptosis, Aspartic Acid, Flavonoids, Caspase, Kaempferol, Quercetin, Rutin
\end{abstract}

(C) RASĀYAN. All rights reserved

\section{INTRODUCTION}

Apoptosis, derived from a Greek word which means to fall away from, is characterized by the hypercondensation of chromatin, the fragmentation of the nucleus (pyknosis), the blebbing of the plasma membrane, the disintegrate of the organelles, the collapse of the nucleus, and the shrinkage of the cell to form apoptotic bodies, respectively. These apoptotic bodies are then removed by macrophages phagocytosis. There are two pathways of apoptosis, i.e. the intrinsic which is caused by internal dysfunction; and the extrinsic which occurs in response to external signals. Both pathways induce cell death by activating caspases. ${ }^{1}$ Apoptosis is caused by activation of cysteine aspartyl proteases (or caspases), i.e. intracellular cysteine proteases which cleave their substrates at aspartic acid residues. ${ }^{2}$ Caspases, a family of dimeric cysteine proteases, involved in apoptosis are categorized into: (1) the initiator caspases (e.g. caspase-9 in mammals) and (2) the effector caspases (e.g. caspases-3 and -7 in mammals). ${ }^{3}$

Caspases could selectively recognize their substrates. ${ }^{4}$ The specific tetrapeptide sequences, which are distinguished by Asp residue at the P1 (C-terminus) and P4 (N-terminus) of caspase-3, refer to its Rasayan J. Chem., 13(3), 1321-1329(2020) http://dx.doi.org/10.31788/ RJC.2020.1335766

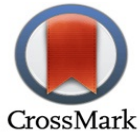


RASĀYAN J. Chem.

Vol. 13 | No. 3 |1321-1329| July - September | 2020

selectivity. Moreover, a highly selective caspase-3 inhibitor was reported could inhibit the hydrolysis of the caspase-3 substrate. This competitive inhibitor attached to the binding pocket of caspase- 3 and blocked the substrate in entering the catalytic site. ${ }^{5}$ Examples of caspases and their substrates are caspase1 and substrate pro-IL-1 $\beta$; caspase-3 and substrate peptide DLVD (DLVD: the amino acid sequence of Asp-Leu-Val-Asp); caspase-1, $-4,-7$ and -8 showed activity for DEVD (DEVD: the amino acid sequence of Asp-Glu-Val-Asp) substrate; caspase-2 substrate is VDVAD (VDAVD: the amino acid sequence of Val-Asp-Val-Ala-Asp). ${ }^{6}$ Human caspases share a common active site cysteine-histidine dyad (His144/Cys 186) located in loop L3 and loop L4. ${ }^{7}$ The caspase substrate binds in an area that comprises of loops L2, L3, and L4 of the first subunit and loop L2' of the second subunit of the caspase dimer. The development of specific active site-directed inhibitors had been considered as unsuccessful, thus, allosteric site inhibitors are more promising drugs. ${ }^{8}$ The binding of allosteric inhibitors has been proven to affect the conformation of the L2 loop which folds over the allosteric cavity. Examples of the allosteric inhibitors are DICA, 2-(2,4 dichloro phenoxy)-N-(2-mercapto-ethyl)-acetamide, and FICA, 5-fluoro-1Hindole-2 carboxylic acid (2-mercapto-ethyl)-amide. These two inhibitors inhibit caspase-3 by interacting with Cys264, an amino acid residue in the deep central cavity at the dimer interface, through a formation of a disulfide bridge. The binding of DICA could inactivate the caspases by cleaving the cation- $\pi$ interaction between two amino acid residues, namely Arg187 and Tyr223. ${ }^{8,9,10}$ Furthermore, FICA and DICA could inactivate the enzyme at three levels: (1) they change the orientation and/or shift Cys186 and His 144 residues from their original location in the catalytic site; (2) they dislocate Arg 187 to the opening of the cavity hence it causes a steric hindrance for substrate binding; and (3) they distort the substratebinding loops. ${ }^{9}$

Corilagin, isolated from Phyllanthus niruri (Phyllanthaceae), was reported could stimulate G2/M cell cycle arrest and blocked cell cycle-related proteins. This compound could inhibit the growth of ovarian cancer cell lines (Hey, SKOv3ip, and HO8910PM) ${ }^{11}$ Quercetin, a flavonol compound, significantly inhibited the proliferation of BT-474 human breast cancer cells in a dose-dependent manner $(20-100 \mu \mathrm{M})$ after $72 \mathrm{~h}$ of treatment. ${ }^{12}$ However, the whole plant ethanolic extract of Acalypha wilkesiana Müll. Arg (Euphorbiaceae) suppressed the growth of breast cancer MDA-MB-468 cells and revealed preference over non-transformed MRC5 fibroblasts. ${ }^{13}$ The ethanol extract and fractions of $A$. wilkesiana leaves showed cytotoxicity against HeLa cervical cancer cell lines $\left(\mathrm{IC}_{50}\right.$ of the ethanol extract $=98.91 \mu \mathrm{g} / \mathrm{mL}$; $\mathrm{IC}_{50}$ of the $n$-hexane fraction $=88.85 \mu \mathrm{g} / \mathrm{mL} ; \mathrm{IC}_{50}$ of the ethyl acetate fraction $=79.84 \mu \mathrm{g} / \mathrm{mL} ; \mathrm{IC}_{50}$ of the water fraction $=102.47 \mu \mathrm{g} / \mathrm{mL}){ }^{14}$

We considered that it would be important to understand the molecular mechanism of A. wilkesiana in inhibiting HeLa cervical cancer cell lines and to discover potential plant-based caspase-3 inhibitors, therefore, in this paper we report a structure-based study of molecular interaction of the downstream executioner caspases with corilagin (Fig.-1a), quercetin (Fig.-1b), rutin (Fig.-1c), kaempferol (Fig.-1d), gallic acid (Fig.-1e), and geraniin (Fig.-1f), bioactive compounds of $A$. wilkesiana Müll.Arg.

\section{EXPERIMENTAL}

\section{Hardware and Software}

Hardware used was MacBook Pro (13-inch, Mid 2012) embedded with macOS Mojave 10.14.6, $2.5 \mathrm{GHz}$ Intel Core i5 processor, 16 GB $1600 \mathrm{MHz}$ DDR3, and Intel HD Graphics $40001536 \mathrm{MB}$. Softwares used were MarvinSketch of ChemAxon 17.11.0 (Academic License), LigandScout 4.1.4 (Universitas Padjadjaran License), AutoDock 1.5.6, AutoDock Vina 1.1 and Discovery Studio Visualizer (Freeware).

\section{General Procedure \\ Preparation of Protein Structures}

The X-ray crystal structure of human caspase-3 in complex with tethered salicylate (PDB ID 1NME) ${ }^{15,16}$ and caspase-7 in complex with FICA allosteric inhibitor (PDB ID 1SHL) ${ }^{9,17}$ (Fig.-2) was downloaded from the Research Collaboratory for Structural Bioinformatics (RCSB) protein data bank (available online: https://www. rcsb.org/structure/). Only $3 \%$ and $2 \%$ of the fractions of residues in chain A (subunit P17) and chain B (subunit P12), respectively, that have poor fit to the electron density. 
RASĀYAN J. Chem.

Vol. 13 | No. 3 |1321-1329| July - September | 2020

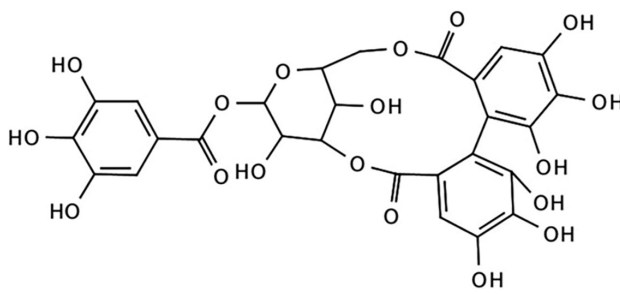

(a)<smiles>O=c1c(O)c(-c2ccc(O)cc2)oc2cc(O)cc(O)c12</smiles>

(d)<smiles>O=c1c(O)c(-c2ccc(O)c(O)c2)oc2cc(O)cc(O)c12</smiles>

(b)

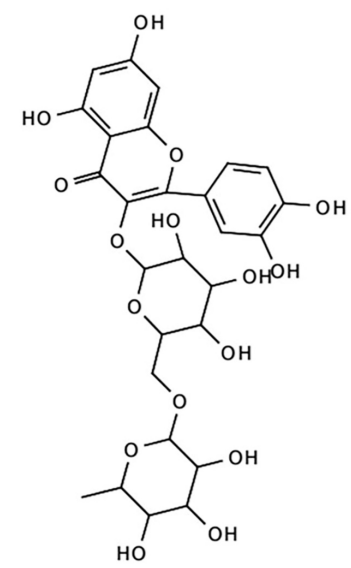

(c) (e)<smiles>O=C(O)c1cc(O)c(O)c(O)c1</smiles>

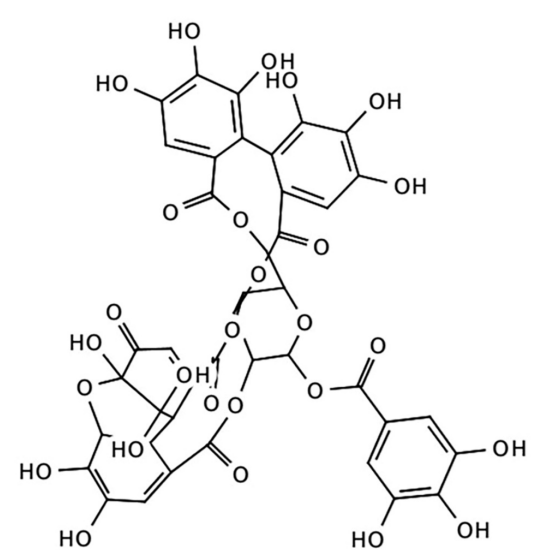

(f)

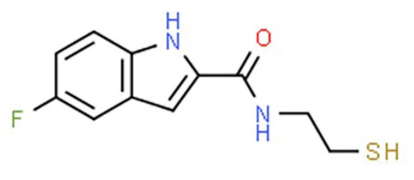

(g)

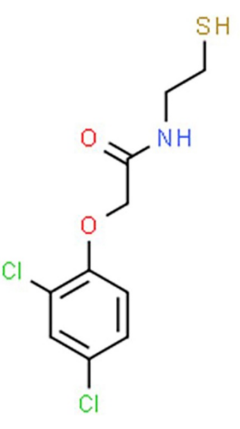

(h)

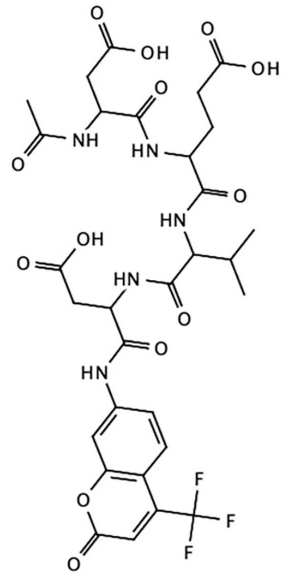

(i)

Fig.-1: 2D Molecular Structure of (a) Corilagin, (b) Quercetin, (c) Rutin, (d) Kaempferol, (e) Gallic Acid, (f) Geraniin; (g) FICA, (h) DICA, (i) Ac-DEVD-AFC (a Caspase-3 Substrate). Structures of the Ligands (a)-(f) and (i) were built using LigandScout Software.

There are 4 unique types of molecules in this entry: (1) caspase-3 subunit P17 (chain A); (2) caspase-3 subunit P12 (chain B); (3) aza-peptide inhibitor (chain C); (4) water (chain A, B, C). The entry contains 
RASĀYAN J. Chem.

Vol. 13 | No. 3 |1321-1329| July - September | 2020

2459 atoms, of which 0 is hydrogen, and 0 is deuterium. The protein structure was refined by using Discovery Studio Visualizer and was subjected to energy minimization using molecular mechanic forcefield MMFF94 ${ }^{18}$ in LigandScout. The interaction of FICA in the allosteric site of caspase-7 and 2hydroxy-5-(2-mercapto-ethyl sulfamoyl)-benzoic acid with amino acid residue in the caspase-3 allosteric site is presented in Fig.-3.

\section{Preparation of the Ligands and Molecular Docking}

The ligands (corilagin, quercetin, rutin, kaempferol, gallic acid, and geraniin) (Fig.-1) were built using MarvinSketch of ChemAxon and were subjected to energy minimization using the MMFF94 forcefield partial charges in LigandScout. ${ }^{18}$ The physicochemical properties of all ligands were determined using the same software. The energy-minimized ligands were docked to the allosteric site of caspase-3 (PDB ID 1NME) and caspase-7 (PDB ID 1SHL) model proteins. ${ }^{15,17}$ Molecular docking was carried out for all the test compounds by employing AutoDock Vina embedded in the LigandScout. During the docking process, the scaling factor for the nonpolar atoms of the receptor was set to 0.8 to allow for some flexibility of the receptor. Besides, all other parameters were used as defaults and the docking procedure was established. The binding affinity of the caspase-3/ligand and caspase-7/ligand complexes were expressed in terms of docking scores.

\section{RESULTS AND DISCUSSION}

In this work, we studied the structure-based molecular interaction of the phytoconstituents (ligands) in Acalypha wilkesiana Müll.Arg with important amino acid residues in the location where the substrate of caspase-3 and caspase-7 binds. Firstly, we analyzed the physicochemical properties of the ligands compared to those of the substrate and the allosteric inhibitors. The physicochemical properties of the ligands are presented in Table-1.

Table-1: Physicochemical Properties of Corilagin, Quercetin, Rutin, Kaempferol, Gallic Acid, and Geraniin

\begin{tabular}{|c|c|c|c|c|c|}
\hline $\begin{array}{c}\text { Name of } \\
\text { Compound }\end{array}$ & Formula (MW) & $\begin{array}{l}\text { Aromatic Atoms } \\
\text { (Rotatable Bonds) }\end{array}$ & $\operatorname{cLog} \mathrm{P}$ & HBA & HBD \\
\hline $\begin{array}{c}\text { Ac-DEVD-AFC } \\
\text { (caspase-3 } \\
\text { substrate) }\end{array}$ & $\begin{array}{l}\mathrm{C}_{30} \mathrm{H}_{34} \mathrm{~N}_{5} \mathrm{O}_{13} \mathrm{~F}_{3} \\
\quad(729.618)\end{array}$ & $10(24)$ & -0.680 & -- & -- \\
\hline $\begin{array}{c}\text { DICA } \\
\text { (allosteric } \\
\text { inhibitor) }\end{array}$ & $\begin{array}{c}\mathrm{C}_{10} \mathrm{H}_{11} \mathrm{~N}_{1} \mathrm{O}_{2} \mathrm{Cl}_{2} \mathrm{~S}_{1} \\
(280.173)\end{array}$ & $6(6)$ & 2.798 & 3 & 2 \\
\hline $\begin{array}{c}\text { FICA } \\
\text { (allosteric } \\
\text { inhibitor) }\end{array}$ & $\begin{array}{c}\mathrm{C}_{11} \mathrm{H}_{11} \mathrm{~N}_{2} \mathrm{O}_{1} \mathrm{~F}_{1} \mathrm{~S}_{1} \\
(238.284)\end{array}$ & $9(4)$ & 2.115 & 3 & 3 \\
\hline Kaempferol & $\mathrm{C}_{15} \mathrm{H}_{10} \mathrm{O}_{6}(286.239)$ & $16(5)$ & 2.282 & 6 & 5 \\
\hline Quercetin & $\mathrm{C}_{15} \mathrm{H}_{10} \mathrm{O}_{7}(302.238)$ & $16(6)$ & 1.988 & 6 & 5 \\
\hline Gallic acid & $\mathrm{C}_{7} \mathrm{H}_{6} \mathrm{O}_{5}(170.120)$ & $6(5)$ & 0.270 & 5 & 3 \\
\hline Corilagin & $\mathrm{C}_{27} \mathrm{H}_{22} \mathrm{O}_{18}(634.455)$ & $18(14)$ & -1.278 & 15 & 11 \\
\hline Rutin & $\mathrm{C}_{27} \mathrm{H}_{30} \mathrm{O}_{16}(610.521)$ & $16(17)$ & -2.260 & 15 & 10 \\
\hline Geraniin & $\mathrm{C}_{41} \mathrm{H}_{28} \mathrm{O}_{27}(952.648)$ & $24(17)$ & -2.887 & 22 & 14 \\
\hline
\end{tabular}

Of all ligands, DICA is the most hydrophobic compound, while geraniin is the most hydrophilic and flexible compound. The flexibility of a ligand is considered important because it affects how the ligand binds to the receptor. According to Koshland (1958) as cited by Lexa and Carlson, when a ligand approaches a receptor, the receptor will eventually change its conformation. This is called a conformational induction or induced fit. Moreover, a ligand can choose a binding partner (and site) that match its conformational status. ${ }^{20}$

The allosteric site of caspase-7, where the inhibitor is attached, consists of the couple residues (Arg187 and Tyr223) and the catalytic dyad residues (His144 and Cys186). The inhibitor is covalently bound to Cys290 (Fig.-3). Residue Gly188 and Tyr229 are also contained in the allosteric site. ${ }^{6}$ The location of the 
RASĀYAN J. Chem.

Vol. 13 | No. 3 |1321-1329| July - September | 2020

allosteric site is $15 \AA$ away from the active site. Mutational and structural analysis revealed a linear circuit of functional residues that runs from one active site through the allosteric cavity and into the second active site. ${ }^{21}$

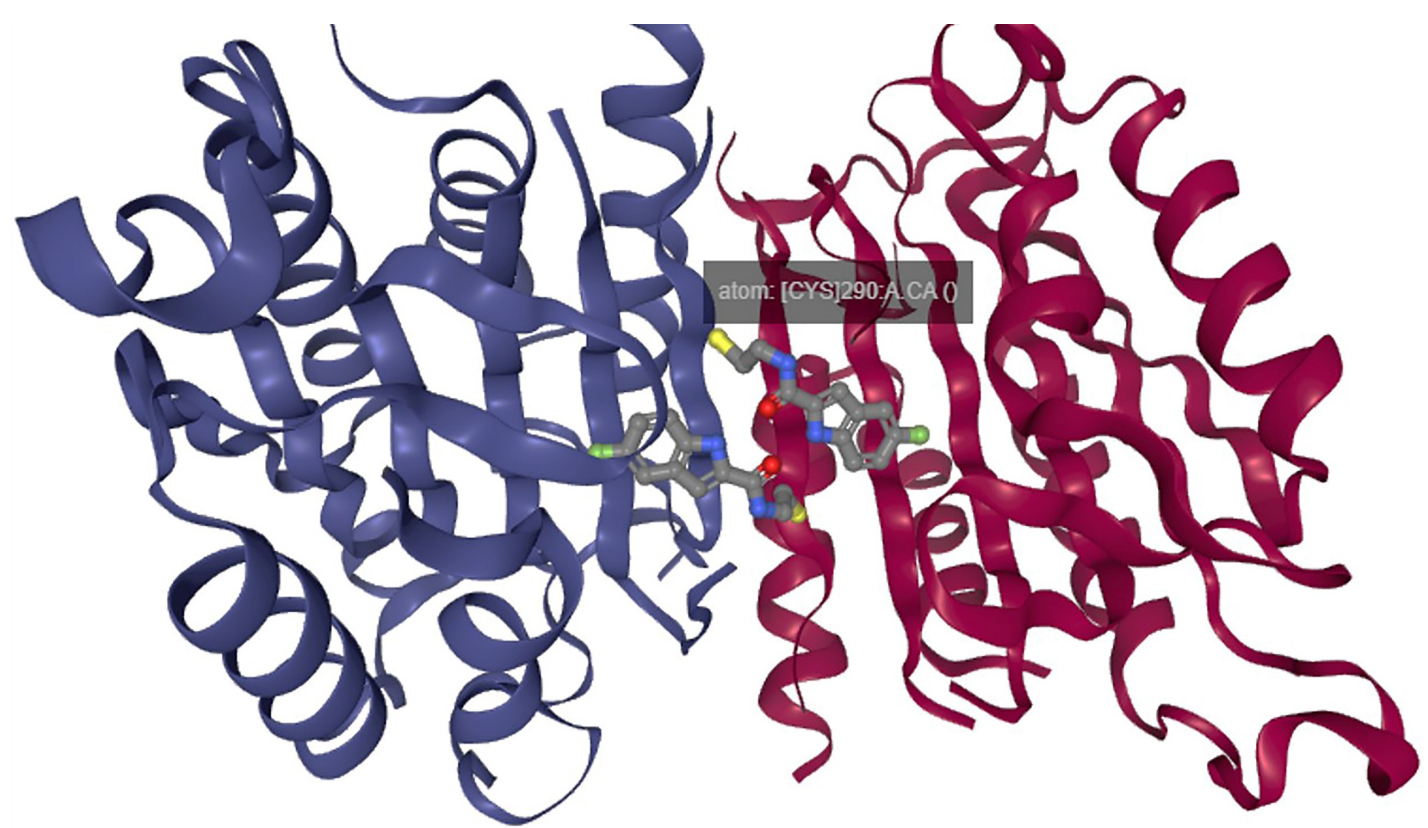

Fig.-2: Two Molecules of FICA are bound in the Allosteric Site of the Caspase-7 Dimer. The Allosteric Site is located at the Interface of the Dimer. The Amino Acid Residue at the Interface is Cys290 (Labeled). Chain A is represented by Blue Ribbon and Chain B is Red (This Picture is Obtained From https://www.rcsb.org/3dview/1SHL/1 ${ }^{17}$ and viewed by Using NGL (WebGL), A 3D Viewer powered by MMTF.

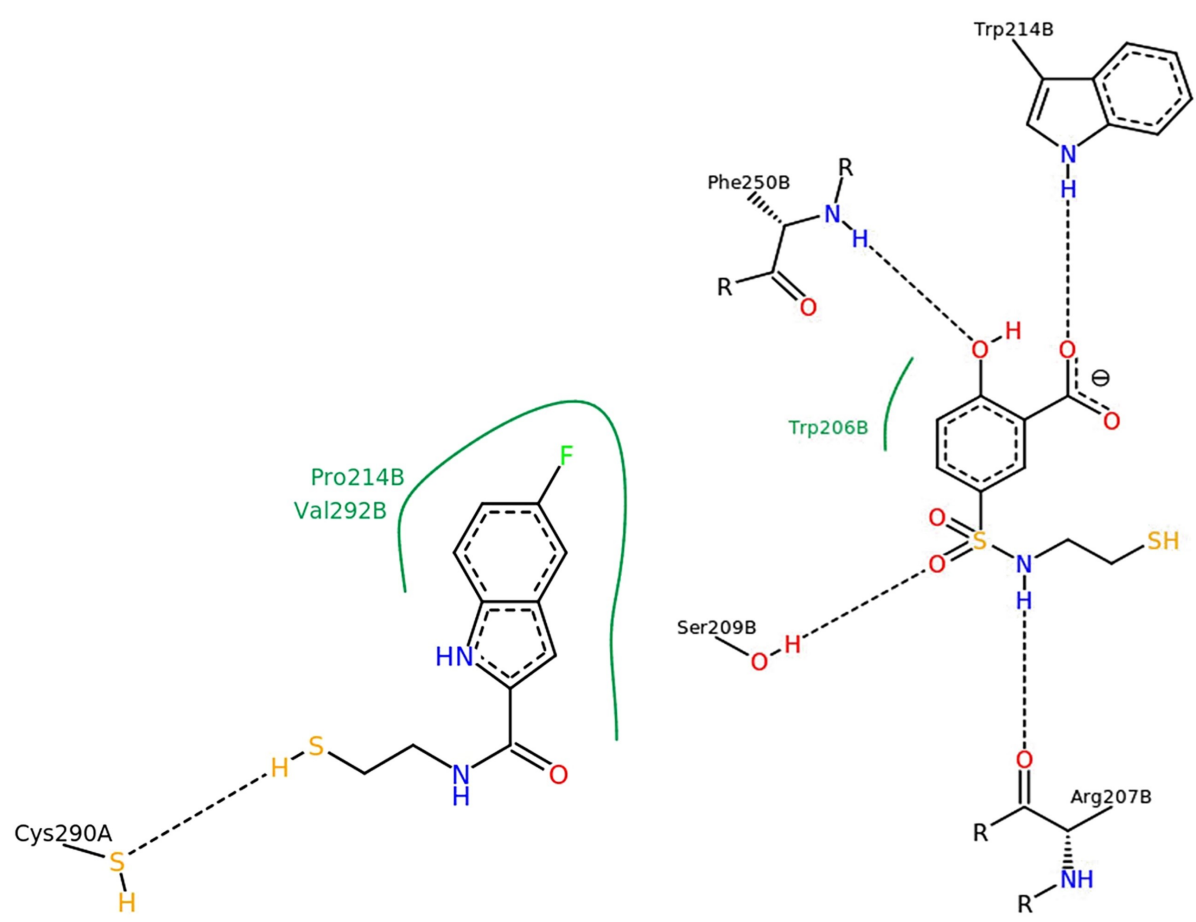

Fig.-3. 2D Diagram for Hydrogen Bond and Hydrophobic Interaction between FICA with Amino Acid Residue in the Caspase-7 Allosteric Site (Left) ${ }^{8}$ and 2-Hydroxy-5-(2-mercapto-ethyl sulfamoyl)-benzoic Acid with Amino Acid Residue in the Caspase-3 Allosteric Site (Right). ${ }^{15}$ Note: Black Dashed Lines indicate Hydrogen Bonds. The Green Solid Line shows Hydrophobic Interaction. Interactions are determined by Geometric Criteria. ${ }^{19}$ 
RASĀYAN J. Chem.

Vol. 13 | No. 3 |1321-1329| July - September | 2020

The binding mode and affinity of the ligands in caspase- 3 and caspase- 7 are presented in Table- 2 and Table-3, respectively.

Table-2: The Binding Mode and Affinity of the Ligands in Caspase-3 Compared to the Substrate (Ac-DEVD-AFC) and the Allosteric Inhibitors (FICA and DICA)

\begin{tabular}{|c|c|c|c|c|}
\hline Name of Compound & $\begin{array}{l}\text { Binding } \\
\text { Affinity } \\
(\mathrm{kcal} / \mathrm{mol}) \\
\end{array}$ & $\begin{array}{c}\mathrm{Ki} \\
(\mu \mathrm{M})\end{array}$ & Hydrogen Bond & Hydrophobic Interaction \\
\hline $\begin{array}{l}\text { Ac-DEVD-AFC } \\
\text { (caspase-3 } \\
\text { substrate) }\end{array}$ & -7.80 & 1.93 & $\begin{array}{c}\text { Arg64A, Gln161A, Arg207B, } \\
\text { Ser205B, Ser209B }\end{array}$ & $\begin{array}{l}\text { Phe256B, Trp206B, } \\
\text { Trp214B }\end{array}$ \\
\hline $\begin{array}{l}\text { FICA (allosteric } \\
\text { inhibitor) }\end{array}$ & -4.61 & 418.99 & $\begin{array}{l}\text { Cys290A, Gly122A, } \\
\text { Ser120A, Ser205B, }\end{array}$ & Thr62A, Tyr204B \\
\hline $\begin{array}{l}\text { DICA (allosteric } \\
\text { inhibitor) }\end{array}$ & -4.40 & 597.13 & Cys163A, His121A, Ser120A & Phe128A, Thr166A \\
\hline Geraniin & -11.10 & 0.01 & $\begin{array}{c}\text { Ser63A, Ser65A, Thr62A, } \\
\text { Asp253B, Glu248B, } \\
\text { Phe250B, Ser209B, Tyr204B }\end{array}$ & -- \\
\hline Corilagin & -10.80 & 0.01 & $\begin{array}{l}\text { Cys163A, His121A, Ser63A, } \\
\text { Thr62A, Ser205B, Ser209B }\end{array}$ & Arg207B \\
\hline Rutin & -9.70 & 0.08 & $\begin{array}{l}\text { Thr62A, Arg207B, Asn208B, } \\
\text { Phe250B, Ser209B, Ser251B }\end{array}$ & -- \\
\hline Quercetin & -8.80 & 0.36 & $\begin{array}{l}\text { Asn208B, Trp206B, } \\
\text { Trp214B, Tyr204B }\end{array}$ & -- \\
\hline Kaempferol & -8.70 & 0.42 & $\begin{array}{c}\text { Arg64A, Gln161A, His121A, } \\
\text { Tyr204B }\end{array}$ & Trp206B \\
\hline Gallic acid & -5.50 & 93.34 & $\begin{array}{l}\text { Arg46A, Cys163A, Gln161A, } \\
\text { His121A, Arg207B, Tyr204B }\end{array}$ & -- \\
\hline
\end{tabular}

Table-3: The Binding Mode and Affinity of the Ligands in Caspase-7 Compared to the Substrate (Ac-DEVD-AFC) and the Allosteric Inhibitors (FICA and DICA)

\begin{tabular}{|c|c|c|c|c|}
\hline Name of Compound & $\begin{array}{l}\text { Binding } \\
\text { Affinity } \\
(\mathrm{kcal} / \mathrm{mol}) \\
\end{array}$ & $\begin{array}{c}\mathrm{Ki} \\
(\mu \mathrm{M})\end{array}$ & Hydrogen Bond & Hydrophobic Interaction \\
\hline $\begin{array}{l}\text { Ac-DEVD-AFC (a } \\
\text { caspase-3 substrate) }\end{array}$ & -7.20 & 5.30 & $\begin{array}{c}\text { Cys290A, Ile213A, } \\
\text { Tyr223B }\end{array}$ & $\begin{array}{c}\text { Phe221A, Tyr223A, Val292A, } \\
\text { Ile159B, Ile183B, Phe221B, } \\
\text { Val292B }\end{array}$ \\
\hline Rutin & -10.50 & 0.02 & $\begin{array}{l}\text { Tyr223A, Thr225A, } \\
\text { Ile213A, Ile213B }\end{array}$ & Tyr223B, Val292B \\
\hline Corilagin & -8.70 & 0.42 & $\begin{array}{c}\text { Ile213B, Thr225A, } \\
\text { Tyr223A }\end{array}$ & -- \\
\hline Kaempferol & -8.60 & 0.50 & Cys290A & $\begin{array}{c}\text { Tyr223B, Phe221B, Ile183B, } \\
\text { Val292B, Ile159B }\end{array}$ \\
\hline Quercetin & -7.40 & 3.78 & Cys290A, Thr225A & Ile213B, Tyr223A, Val215B \\
\hline Geraniin & -6.60 & 14.59 & $\begin{array}{c}\text { Gln287A, Thr225A, } \\
\text { Tyr223A }\end{array}$ & -- \\
\hline Gallic acid & -4.90 & 256.87 & Cys290A & Ile213B \\
\hline $\begin{array}{l}\text { DICA (allosteric } \\
\text { inhibitor) }\end{array}$ & -4.65 & 391.64 & Cys290A, Ile213B & $\begin{array}{c}\text { Ile159B, Ile183B, Phe221B, } \\
\text { Tyr223B, Val292B }\end{array}$ \\
\hline $\begin{array}{l}\text { FICA (allosteric } \\
\text { inhibitor) }\end{array}$ & -4.27 & 743.57 & Cys290A & $\begin{array}{c}\text { Ile213B, Met294B, Phe221B, } \\
\text { Val215B, Val292B }\end{array}$ \\
\hline
\end{tabular}

Of all studied ligands, kaempferol (Fig.-4 left) shows a similar binding mode, in terms of hydrogen bond (Arg64, Gln161, His121, Tyr204 in caspase-3; Cys290 in caspase-7) and hydrophobic interaction (Trp206 
RASĀYAN J. Chem.

Vol. 13 | No. 3 |1321-1329| July - September | 2020

in caspase-3; Tyr223, Phe221, Ile183, Val292 in caspase-7), with that of Ac-DEVD-AFC (a caspase substrate) (Fig.-4 right) in caspase-3 and caspase-7. Thus, kaempferol is predicted could interact with the executioner caspase- 3 and caspase- 7 in the location where the substrate binds, with better affinity compared to the substrate.
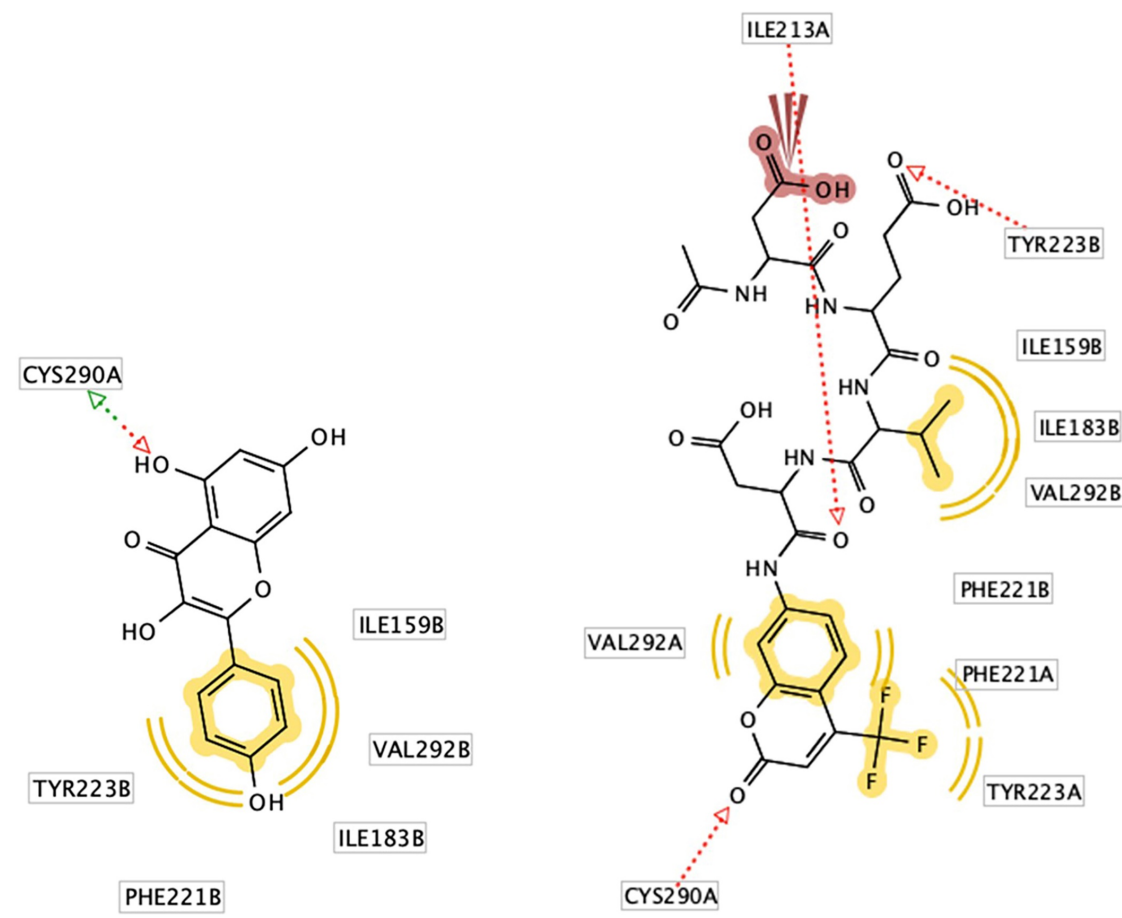

Fig.-4: The Binding Mode of Kaempferol (Left) and Ac-DEVD-AFC, a Caspase Substrate (Right) with Amino Acid Residues in Caspase-7. The Hydrogen Bond is Shown as a Dotted-arrow, While the Hydrophobic Interaction is Visualized by the Yellow Highlight.

Furthermore, the binding mode of rutin (Fig.-5 Left) in terms of hydrogen bond (Ile213) and hydrophobic interaction (Tyr223 and Val292), resembles that of DICA in caspase-7 (Fig.-5 Right). Thus, rutin is predicted could interact with the executioner caspase-7 in the allosteric site, with better affinity compared to DICA.

Thus, kaempferol and rutin, two flavonoids in Acalypha plant, might be able to inhibit the downstream executioner caspases, particularly caspase- 3 and caspase-7, although these compounds exhibit a different mechanism. Kaempferol interacts with caspase-3 and caspase-7 in the substrate's site, whereas rutin interacts with caspase-7 in the allosteric site.

The interaction of kaempferol and rutin, two flavonoids contained in Acalypha plants, with caspase- 3 and caspase-7 might be important in explaining why the ethanol extract and fractions of $A$. wilkesiana leaves indicated cytotoxicity against HeLa cervical cancer cell lines. ${ }^{14}$ Moreover, a combination of $\alpha$-tocopherol and $A$. wilkesiana extract could trigger apoptosis in the human brain and lung cancer cells. ${ }^{22}$ Another study of $A$. wilkesiana as an adjuvant cancer therapy proved that combined treatments of $\beta-, \gamma$ - and $\delta$ tocotrienols and ethyl acetate extract of this plant resulted in synergistic inhibitory on the growth of A549 and U87MG cancer cells. ${ }^{23}$ The ethyl acetate and hexane extracts of $A$. wilkesiana seeds also showed cytotoxicity in human U87MG and A549 cancer cells by cleaving DNA single and double strands. ${ }^{24}$

Flavonoids were proven in possessing various pharmacological activities. Several flavonoids of Crotalaria pallida Aiton have been reported in activating apoptotic proteins in MCF-7 breast cancer cells. ${ }^{25}$ A particular flavonoid, quercetin, has been successfully labeled with ${ }^{99 \mathrm{~m}} \mathrm{Tc}$ to produce ${ }^{99 \mathrm{~m}} \mathrm{Tc}$ quercetin (labeling efficiency of $98.52 \pm 0.96 \%$ ) for cancer radiotracer ${ }^{26}$ Furthermore, flavonoids were also reported could competitively inhibit the caspase-1, -3 , and -7 despite their cellular toxicity. Interestingly, the concentration of flavonoid that inhibits the caspase- 3 and caspase- 7 is equal to that 
RASĀYAN J. Chem.

Vol. 13 | No. 3 |1321-1329| July - September | 2020

which kills the breast adenocarcinoma human cells. In this study, kaempferol has been proven could inhibit caspase-1 $(\mathrm{Ki}>300 \mu \mathrm{M})$; caspase-3 $(\mathrm{Ki}=194.3 \mu \mathrm{M})$; caspase-7 $(\mathrm{Ki}>300 \mu \mathrm{M}){ }^{27}$ A subclass of flavonoids, namely chalcones, characterized by the absence of ring $\mathrm{C}$ of the general flavonoid structure, have been reported in possessing high anticancer activity against various types of cancer cell lines, e.g. MCF7, T47D, HeLa, and WiDr. ${ }^{28}$

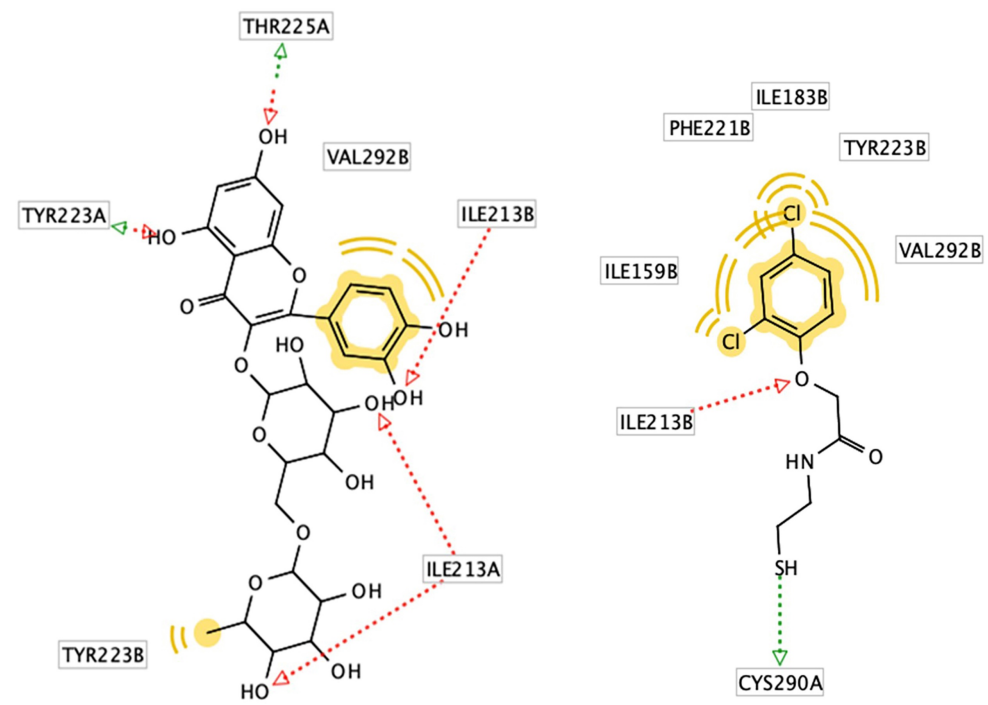

Fig.-5: The Binding Mode of Rutin (Left) and DICA, A Known Allosteric Inhibitor of Caspase (Right) with Amino Acid Residues in Caspase-7. The Hydrogen Bond is Shown as a Dotted-arrow, While the Hydrophobic Interaction is Visualized by the Yellow Highlight.

\section{CONCLUSION}

Kaempferol and rutin, two flavonoids in Acalypha wilkesiana Müll.Arg, might be able to inhibit the downstream executioner caspases, particularly caspase-3 and caspase-7. Kaempferol interacts with caspase- 3 and caspase- 7 in the substrate's site thus competitively replaces the substrate, whereas rutin only interacts with caspase-7 in the allosteric site, similar to DICA, a known allosteric inhibitor. The binding affinity of these compounds against caspases is better than the standards. This study might contribute a molecular insight into understanding the anticancer activity of $A$. wilkesiana.

\section{ACKNOWLEDGMENT}

The publication fee is funded by Universitas Padjadjaran via the Directorate of Research and Community Engagement (DRPM) Universitas Padjadjaran 2020.

\section{REFERENCES}

1. M. Ahmed, A.M. Kabel, A.A. Adwas, A.A. Elkhoely, M.N. Abdel-Rahman, and A.A. Eissa, Journal of Cancer Research and Treatment, 4(4), 69(2016), DOI:10.12691/jcrt-4-4-3

2. J.C. Reed, American Journal of Pathology, 157(5), 1415(2000).

3. Y. Shi, Protein Science, 13, 1979(2004), DOI:10.1110/ps.04789804

4. N.A. Thornberry, K.T. Chapman, and D.W. Nicholson, Methods Enzymology, 322, 100(2000), DOI:10.1016/s0076-6879(00)22011-9

5. T. Schroeder, J. Barandun, A. Flütsch, C. Briand, P.R.E. Mittl, and M.G. Grütter, Structure, 21(2), 277(2013), DOI:10.1016/j.str.2012.12.011

6. M. Poręba, A. Stróżyk, G.S. Salvesen, and M. Drąg, Cold Spring Harbor Perspectives in Biology, 5(8), a008680(2013), DOI:10.1101/cshperspect.a008680

7. K. McLuskey and J.C. Mottram, Biochemical Journal, 466(Pt 2), 219(2015), DOI: $10.1042 / \mathrm{BJ} 20141324$ 
8. J.A. Hardy and J.A. Wells, The Journal of Biological Chemistry, 284(38), 26063(2009), DOI: 10.1074/jbc.M109.001826

9. J.A. Hardy, J. Lam, J.T. Nguyen, T. O'Brien, and J.A. Wells, Proceedings of the National Academy of Sciences USA, 101(34), 12461(2004), DOI: 10.1073/pnas.0404781101

10. R.N.V. Krishna Deepak, A. Abdullah, P. Talwar, H. Fan, and P. Ravanan, Proteins: Structure, Function, Bioinformatics, 86(11), 1202(2018), DOI: 10.1002/prot.25601

11. L. Jia, H. Jin, J. Zhou, L. Chen, Y. Lu, Y. Ming, and Y. Yu, BMC Complementary and Alternative Medicine, 13(33), 1(2013), DOI:10.1186/1472-6882-13-33

12. H.S. Seo, J.M. Ku, H.S. Choi, Y.K. Choi, J.K. Woo, M. Kim, I. Kim, C.H. Na, H. Hur, B.H. Jang, Y.C. Shin, and S.G. Ko, Oncology Reports, 36(1), 31(2016), DOI:10.3892/or.2016.4786

13. J.H.Y. Chu, Investigating In-vitro Anticancer Properties of Malaysian Rainforest Plants: Acalypha wilkesiana Müll, Arg. Archidendron ellipticum (Blume) Hassk, Duabanga grandiflora Walp. Pseuduvaria macrophylla (Oliv.) Merr. PhD Thesis, 2014, University of Nottingham.

14. E. Halimah, I.M. Puspitasari, and F. Ferdiansyah, Research Journal of Chemistry and Environment, 22(S1), 28(2018).

15. D.A. Erlanson, J.W. Lam, C. Wiesmann, T.N. Luong, R.L. Simmons, W.L. DeLano, I.C. Choong, M.T. Burdett, W.M. Flanagan, D. Lee, E.M. Gordon, and T. O'Brien, (2003), DOI: $10.2210 / \mathrm{pdb} 1 \mathrm{nme} / \mathrm{pdb}$

16. D.A. Erlanson, J.W. Lam, C. Wiesmann, T.N. Luong, R.L. Simmons, W.L. DeLano, I.C. Choong, M.T. Burdett, W.M. Flanagan, D. Lee, E.M. Gordon, and T. O'Brien, Nature Biotechnology, 21, 308(2003), DOI:10.1038/nbt786

17. J.A. Hardy, J. Lam, J.T. Nguyen, T. O'Brien, and J.A. Wells, (2004), DOI:10.2210/pdb1SHL/pdb

18. P. Tosco, N. Stiefl, and G. Landrum, Journal of Cheminformatics, 6, 37(2014)

19. K. Stierand and M. Rarey, ACS Medicinal Chemistry Letters, 1(9), 540(2010), DOI: $10.1021 / \mathrm{ml} 100164 \mathrm{p}$

20. K.W. Lexa and H.A. Carlson, Quarterly Reviews of Biophysics, 45(3), 301(2012), DOI: $10.1017 \% 2 \mathrm{FS} 0033583512000066$

21. J.M. Scheer, M.J. Romanowski, and J.A. Wells, Proceedings of the National Academy of Sciences of the United States of America, 103(20), 7595(2006), DOI:10.1073/pnas.0602571103

22. S.W. Lim, H.S. Loh, K.N. Ting, T.D. Bradshaw, and N.A. Zeenathul, International Journal of Bioscience, Biochemistry and Bioinformatics, 3(4), 335(2013).

23. I.B. Abubakar, S.W. Lim, and H.S. Loh, Tropical Life Sciences Research, 29(1), 229(2018), DOI: $10.21315 / \mathrm{t} \mathrm{sr} 2018.29 .1 .15$

24. S.W. Lim, K.N. Ting, T.D. Bradshaw, N.A. Zeenathul, C. Wiart, T.J. Khoo, K.H. Lim, and H.S. Loh, Journal of Ethnopharmacology, 138(2), 616(2011), DOI:10.1016/j.jep.2011.10.005

25. E.M. Rumondor, M. Moektiwardoyo, and M.I. Barliana, Pharmacology and Clinical Pharmacy Research, 2(3), 63(2017), DOI:10.15416/pcpr.v2i3.16218

26. E.M. Widyasari, M.Y.A. Simarmata, M. Marzuki, M.E. Sriyani, R.J. Sugiharti, and W. Nuraeni, Rasāyan Journal of Chemistry, 12(1), 278(2019), DOI:10.31788/RJC.2019.1215052

27. J.B. White, J. Beckford, S. Yadegarynia, N. Ngo, T. Lialiutska, and M. d'Alarcao, Food Chemistry, 131(4), 1453(2012), DOI:10.1016\%2Fj.foodchem.2011.10.026

28. A.A.T. Suma, T.D. Wahyuningsih, and Mustofa, Rasāyan Journal of Chemistry, 12(2), 502(2019), DOI: $10.31788 /$ RJC.2019.1225020

[RJC-5766/2020] 